\title{
Description of the Psychological Needs of Klitih Perpetrators in Yogyakarta Using Thematic Apperception Test (TAT)
}

\author{
Dessy Pranungsari \\ Faculty of Psychology \\ Universitas Ahmad Dahlan \\ dessy.pranungsari@psy.uad.ac.id \\ Marina Yollanda \\ Faculty of Psychology \\ Universitas Ahmad Dahlan \\ marina.yollanda96@gmail.com
}

\author{
Muhammad Hidayat \\ Faculty of Psychology \\ Universitas Ahmad Dahlan \\ muhammad.hidayat@psy.uad.ac.id \\ Miftah Sa'adah Maulidiyah \\ Faculty of Psychology \\ Universitas Ahmad Dahlan \\ m4ulidiya@gmail.com
}

\begin{abstract}
This study aims to determine the psychological needs of klith perpetrators in Yogyakarta. The main objective of this research was to describe the psychological needs of klitih perpetrators in Yogyakarta. This study's participants consist of three males with the following criteria: (I) aged 18-24, (2) klitih perpetrators, and (3) lives in Yogyakarta. The research method used was qualitative research using a phenomenological approach. Data collection was conducted using the Personality Test (TAT), equipped with an interview. Data analysis was conducted using thematic analysis. The findings reveal five dominant psychological needs of klitih perpetrators, such as the need for warmth and support (need for affiliation) and the need to seek help or sympathy (need for succorance). The need for freedom (need for autonomy) appeared to emerge strongly against the pressure from permissive and less warm family background, causing the participant to spend more time outside their homes. The need for violence (need for aggression) and the need for recognition (need for achievement) also appeared to arise due to the social environment's demands, which then influence the participant to commit acts of klitih. This research shows the psychological needs of klith perpetrators that can be channeled through other activities. Therefore, alternative positive activities that can meet these five primary needs should be developed to prevent adolescents from being involved in acts of klitih in schools, families, communities, and the Yogyakarta government.
\end{abstract}

Keywords: Klitih, Psychological Needs, TAT.

Received 26 December 2020/Accepted 9 March 202I (A)Athor all rights reserved

\section{Introduction}

Juvenile delinquency is not a novel problem. From time to time, issues revolving around juvenile delinquency continue to occur. The international world also focuses on juvenile delinquency in several countries. One of them is that in the United States of America, juvenile delinquency has become a national issue. Thus, the prevention of such acts is recommended to be a national priority 
(Bushman et al., 2016). According to WHO (2019) data, as many as 40\% of adolescents aged 10-29 have had physical fights. It is not much different from the international issue of juvenile delinquency or violence in Indonesia, which is still rife. The factors that cause it and how to manage it are still being studied and researched (Fatimah \& Umuri, 2014; Sumara, Humaedi \& Santoso, 2017; Oktoviani \& Lukmawati, 2018; Andrianto \& Alimron, 2019). In Yogyakarta, juvenile delinquency, often referred to as klitih, continues to occur. Quoting from Tribun (2018), there were 13 klitihcases in Yogyakarta with two fatalities in 2018. This situation is a real issue for the Yogyakarta people, who are comprised of a large student population and are known as the city of students.

The word klitih derived from the Javanese language nglitih, meaning looking for something to do in leisure time. The word klitih was associated with adolescents and defined as students who go around in groups using a vehicle (motorbike) (Syafi'ie, 2017). The definition of klitih became blurred when it comes to juvenile delinquency. According to the traditional definition, looking for something to do in leisure time is considered a positive action. However, klitih is currently defined as the behavior of adolescents who drive around using vehicles looking for enemies from other schools to commit acts of violence (Sugiarti, 2017). Syafi'i (2017) stated that klitih is an activity of roaming around (by riding a motorcycle or other vehicles) then committing acts of violence and even the act of taking someone's life. Klitih was usually conducted by a gang, team, or group of brawls. It revolves around looking for prey on the streets on a motorbike.

Based on research conducted by Fuadi, Mutiah, and Harjosuno (2019), parenting styles and problematic family conditions such as lack of affection from parents contributed a lot to klitih behavior. Additionally, this behavior is also influenced by the perpetrator's relationship with the group. The more courageous and the more actions are taken to practice klitih behavior, the stronger the group's recognition. The next factor is the perpetrator's relationship with the environment. Perpetrators were raised in a neglectful environment, where there are no rules or consequences. As there were no consequences when the perpetrator committed a mistake, the perpetrator got used to doing whatever he/she likes. Research by Casmini and Supardi (2020) showed that adolescents could suppress the emergence of klitih because of the strong religious values, communication, behavior control, and self-esteem found in the family environment. 
Lack of affection from the family and neglectful environment has made it difficult for klitih perpetrators to control their emotions. Winarno (2020) emphasized that klitih is a manifestation of aggression deviation among adolescents in the form of failure to express aggression and sublimate it to positive aggression forms. Meanwhile, the determinant factor of klitih is conformity. Negative conformity in friendship groups caused adolescents to commit actions that harm the perpetrator and other people or society (Kipping, Campbell, MacArthur, Gunnell, \& Hickman, 20I2). From this explanation, klitih can be seen as the only means for adolescents to regain their parents' attention and to ventilate their emotions (Fuadi et al., 2019).

From some of the explanations above, it can be concluded that klitih is a negative behavior of looking for something to do leisurely. This behavior is also shown through aggressive behavior that adolescents display to show their self-existence, seeking family attention, especially parents, and as a form of emotional outlet.

The main objective of this research was to describe the psychological needs of klitih perpetrators in Yogyakarta. This topic was considered necessary because psychological needs are one of the primary needs that must be met. According to Murray, unmet psychological needs would lead to psychological problems such as depression (Hall \& Lindzey, 1993). The unmet psychological needs of adolescents also impact the development of negative behavior, one of which is gun violence (Ozdemir, Utkualp \& Pallos, 2016). Research conducted by Yusri and Jasmienti (2017) also showed that one of the implications of having unfulfilled psychological needs is aggressive behavior. The originality and renewal of this research lay in the data collection process. In addition to interviews, participants were also given a projective personality test (i.e., Thematic apperception test) to explore their needs that became the basis for performing klitih behavior.

Murray further explained that every person's behavior was conducted to fulfill the needs. Fulfilling those needs would make a person experience a better condition, calmer, and more satisfied. Vice versa, needs that could not be met would cause feelings of disappointment, and it might also cause the individual to feel pressured (Hall \& Lindzey, 1993). Therefore psychological needs that cannot be fulfilled in adolescents would lead to the development of negative behavior and the potential for aggressive behavior (Ozdemir, Utkualp \& Pallos, 2016; Yusri \& Jasmienti 2017). 
Based on the above background, it is essential to have research that provides an overview of klitih perpetrators' needs in Yogyakarta. Research on the developmental pathway of klitih behavior (Febriani, 2018) and the dynamics of klitih perpetrators' self-concept (Moranita and Huda, 2019) has been conducted in Indonesia. A study on juvenile delinquency personality has also been conducted by Gungea, Jaunky \& Ramesh (2017), even though it was not explicitly focused on the klitih phenomenon. This study wanted to see a picture of the psychological dynamics related to the perpetrators' personality by collecting data from interviews and TAT personality tests. This research was expected to provide an overview of the psychological needs of adolescent klitih perpetrators in Yogyakarta. The findings from this study would later be used as additional references and recommendations for related parties for prevention and handling related to violent behavior in adolescents, which was the klitih behavior in Yogyakarta.

\section{Research Question}

The formulation of the problem in this study was How to describe the dynamics of the perpetrators' psychological needs involved in klitih behavior in Yogyakarta?

\section{Method}

\section{Research Design}

This study used a qualitative method because the researcher wanted to see the psychological dynamics of the klitih perpetrators. The qualitative approach used in this research is the phenomenological approach. Phenomenology is a way of thinking that emphasizes subjective experiences and their interpretations. Researchers tried to understand the meaning of events and their relation to different people in certain situations. In this approach, researchers tried to enter into the conceptual world of the participant under study to understand the life events of the participants (Moleong, 20II).

The data collection was conducted using interview methods and a projective personality test: Thematic Apperception Test (TAT). Interviews were intended to reveal past conditions, family, social interactions, and others. Meanwhile, TAT was intended to reveal matters relating to the 
psychological needs of the participant. TAT was also intended to look at recurring themes that appear on the participant, revealing information related to the participants' needs, pressures, emotions, feelings of sentiment, complexity, and conflict (Anastasi \& Urbina, 1998; Aiken \& GrothMarnat, 2009). The TAT projective personality test can be used as stimulation to reveal a picture of individuals' psychological needs (Reber \& Reber, 2010).

The Thematic Apperception Test (TAT) is a tool with a projective technique developed by Christina Morgan and Henry Murray. The TAT stimuli are several ambiguous images designed to stimulate the observer's imagination and reveal areas that are motivationally specific and detect conflict opportunities (Alwisol, 2009). TAT consists of 30 picture cards about people in different social and solitary situations and one blank card (Bellak and Abrams, 1997). Of the total cards, ten standard cards can be used for all ages and genders: cards I, 2, 3BM, 4, 6BM, 7GF, 8BM, 9GF, 10, and I3MF. 2I other cards are supplementary cards according to the assessment results and the needs that need to be disclosed (3GF, 5, 6GF, 7BM, 8GF, 9BM, II, I2M, I2F, I2BG, I3B, I3G, 14,15, 16, I7BM, I7GF, I8BM, I8GF, 19, 20, blank card). In the study, researchers only used ten standard cards plus three additional cards; they were 9BM, 16, and 18 BM cards. These supplementary cards were selected based on the needs related to social relations and friendship, which would be revealed in this study.

In addition to clinical needs and assessment, clinical psychologists often use TAT because it can reveal things that are not realized, especially related to needs. The interpretation method used was the content analysis method, where the participant was asked to tell a story of an ambiguously designed card (Bellak \& Abrams, 1997).

\section{Research participants}

The participant selection was conducted using the participant-taking method based on theory or based on operational constructs (theory-based/operational construct sampling). The characteristics of the participants in this study were male, 18 - 24 years old and klitih perpetrator. 
The number of participants in this study was three people who had filled in the informed consent. This sample size was under the principles of qualitative research, which emphasizes depth and process so that it tends to be done in small numbers. The research location was Yogyakarta.

Data Collection

Interview

One of the data collection methods used was the semi-structured in-depth interview technique to get a better understanding of the context of things that happened. This method is characterized by openness, discovery-oriented, and sufficient space for research participants to tell their experiences and perspectives. The interview was conducted in Yogyakarta in a shop/cafe requested by the participants because they did not want the researcher to visit the house. Interviews were conducted in December 2019, which included initial interviews and in-depth interviews.

\section{Psychological Test}

The psychological test in this study was intended to provide an overview of the psychological needs of the klitih perpetrators through a projective personality test (TAT). The test was conducted at the UAD Psychology laboratory on Sunday because the participants were unwilling to meet many people.

\section{Data Analysis}

Data obtained from interviews and psychological tests were analyzed using a constant comparative approach using content/theme analysis (Poerwandari, 2009). Data analysis procedures were as follows: systematic data organization, coding, and analysis, testing of assumptions, analysis strategies, interpretation.

\section{Results}

The following are the results of interviews with the participants:

Participant I (AA)

The participant is the first child of two. The participant's parents have been divorced since he was in grade IV in primary school. Since childhood, the participant often received lessons about the 
values or norms of life from his grandparents. The relationship pattern in the participant's family tends to be distant. The mother gave no rules in the house. Apart from being busy with his job as a mechanic in a car repair shop, he is often involved in community activities. Among them are being a football supporter, party activist, and alumni community from his previous school. This community is engaged in social activities such as initiating syawalan (led Al-Fitr) activities, social services, and fundraising. According to the participant, this community was formed since he was in high school. Even these community members are students who used to be labeled as delinquents at school. This label is due to the behavior of group members who often violate school norms. This community often performs brawl against other schools. Participant joined this community because of feelings of revenge due to being targeted by the community group from another school. The participant succeeded in becoming a leader in the community. This community has very high solidarity. In the community, evaluations are also routinely carried out after engaging in brawls with other parties. The brutality of this community is also illustrated when they deliberately seek out enemy schools to attack. However,suppose they do not find enemy schools. In that case, community members do not hesitate to hurt others who are not related to the community. However, the participant said that he often felt afraid and anxious when he was about to do a brawl. At that time, the participant's concern revolved around winning the brawl and fear of being one of the injured victims due to a sharp object. In a brawl, usually, community members use sharp weapons such as sickles and blunt objects such as iron and stone.

During his time as part of the community, the most dangerous act had committed was beating students from the enemy school until one of the victims broke his hand. The participant also put the victim's vehicle into the rice field and threw away the key, making the victim even more helpless. The participant had also expressed his disappointment at not finding an enemy school on the road by throwing stones at a group of men playing chess. The participant had also wrongly targeted a person. He intended to attack a student from an enemy school. However, he later found out that the victim turned out to be a University student at a public university in Yogyakarta. During this time in the community, the participant has been caught five times by the authorities. The mother and residents in the neighborhood where the participant lives were unaware that the authorities caught him due to his violent behavior. In his home environment, the participant acts as 
chairman of the mosque youth association. Thus, the image that develops in the community was that he is a good religious child.

\section{Participant 2 (SR)}

The participant is the first child of two. Since childhood, the participant was abandoned by his father and mother,who work in a bakery until now. As a child, the participant was often entrusted to his grandmother when his parents left him to work. In grandmother's care, the participant is quite spoiled. As his parents were busy at work, the participant rarely spent time with his parents at home. Even so, the participant tended to be closer to the mother when compared to the father. The participant's relationship with his younger sibling is not too close. They often had disagreements, especially when borrowing personal belongings. The parenting style of the participant's parents tends to be permissive and lacks supervision. At school, the participant often bullies his friends,intending to joke. Since junior high school, the participantoccasionally skipped class and was late for school. When the participant was a vocational high school student, he was more likely to be absent because of the influence of their friends. In school, the participant is a student who is quiet, polite with the teacher, and never joins the school gang. The participant's grades are also good enough so that they never fall behind in class.

Since junior high school, the participant has started smoking, and his parents let him because his father also smoked. The participant's family does not know that he is following the gang. Since the end of grade 3 of junior high school, the participant joined the gang because his friend invited him. When gathering with gang friends, participant activities were chatting, smoking, and sometimes also consuming alcohol, especially when they were going to practice klitih. This was done in order to be more courageous when doing klitih behavior. When he was a football supporter, the participant also often consumed liquor before supporting. In the gang, the participant serves or acts as a jockey (motorbike driver) when performing klitih.

Klitih is usually performed at night until early morning (when it is still dark) by visiting the opponent's headquarters. There is no commercial purpose for this action. The goal is to teach the person or gang that they are their opponents. It is also meant to show that the gang is stronger, 
which gives them a sense of satisfaction after doing it - the reason why the participant keeps on joining the gang because he likes hanging out with his friends. The participant also gets satisfaction and pride because he is stronger than his opponent after performing klitih. At home, the participant felt lonely with no friends because his parents worked. The participantis also rarely at home as he spent more time with his friends outside. The participant also lacks interaction with friends in his place of residence because many have worked. Currently, the participant rarely performs klitih because many of his friends are already working and rarely gather. When several gang members can hang out, it is usually just "hanging out" while chatting. When asked about the participant's view of the future, the participant said that his future was still blurry because he had not thought about what he wanted to achieve in the future. The participant said that he lacked skills but would try to find work soon.

\section{Participant 3 (YD)}

The participant is the first child of four. At home, the participant lives with both parents and his younger siblings. The participant is closer to his mother than his father. He often tells various things about himself to his mother-the participant rarely communicated with his father because he was busy working from morning to evening. The participant's father is a quiet figure and rarely invites the participant to speak. In taking care of the participant, the mother is more dominant than the father, as hisfather tends to leave the participant's care to his mother. When the participant make a mistake, the mother always reprimands while the father tends to be silent. Although the participant considered himself closer to the mother, the mother figure was considered a fierce figure because she often scolded him using verbal language with a high tone of voice. The participant's mother has never done physical violence to the participant and tends to use verbal language. However, sometimes his mother also slams things when scolding the participant. The participant's relationship with his first younger brother was not close because they often fought to the point of physical involvement

Since grade 5 of elementary school, the participantwas introduced to cigarettes from a friend and began smoking in grade 2 of junior high school without parents' knowledge. The participant began to show negative behavior when entering high school, as he often skipped school from grade 10 to grade 12 . The participant skipped school because friends from different schools always invited him. 
When skipping school, the participant and his friends usually gather at one of his friends' houses. Participant played PlayStation and mobile legend online game with friends during the times when he skipped school. The participant felt happy and had fun when he skipped school because he received pocket money from his parents even though he did not go to school. Since grade 10, the participant has often been given warning letters for truancy behavior. However,he did not give them to his parents. When the participant was in grade II, his mother found out that the participant often skipped school because the counseling teacher contacted her. Hence, the mother's response was to be angry using verbal language and sold the participant's motorbike. Even though he had been reprimanded and sanctioned by the school and his mother, the participant still violated school rules and skipped school until grade 12. He was almost expelled from school for truancy for one week. When in high school, the participant also often went out of the house to hang out with friends and came home late at night. His mother scolded him, but the participant ignored her and kept repeating his behavior.

In the first grade ofhigh school, his seniors selected him to enter the gang. This act has been passed down from generation to generation. When the participant became a member of the gang, he felt proud. The participant and his gang group performed klitih, brawl, and gathered in angkringan (latenight snack stand). The participant explained the concept of klitih as bullying and fighting the opponent school. In this case, the opponent school referred to schools where his seniors have always thought of as the enemy and have been passed down from generation to generation until now. If the participant meets a student from an enemy school on the street on his way home, the participant and friends will make fun of the student by taking the student's motorbike key and leaving. In the participant's gang, an agreement has also been made that it is only acceptable to perform klitih to a group of students who wear uniforms and not a citizen. The participant also stated that he felt happier when he gets a student who went to an enemy school. Participant and his friends usually also brawl for bets with enemy schools. The brawl was carried out on a motorbike by carrying dangerous objects (i.e., stones, broken tile, woods, baseball sticks, glass bottles). Some students were even carrying swords, but the participant statedhe did not carry swords. The participant usually does not carry equipment with serious risks such as swords or knives because he did not want to hurt others. During a brawl or when one clash using a motorbike, there are jockeys (who drive the motorbike) and fighters (who hitchhikes to attack). Currently, the 
participant has stopped performing klitih because he has graduated from school. The participant also realized that performing klitih did not have any positive benefits as he only gained recognition from his friends. At this time, the participant became afraid of the police and worried that he would be arrested because he already had an ID card. Participant hopes to be a better person and pursue education according to the major he is interested in, which is accounting.

The following are the TAT results of the participants:

Participant I (AA)

Based on the Thematic Apperception Test(TAT) results, it can be concluded that the participant is an individual who has a strong curiosity. The participant also has a good fighting power to realize this curiosity. However, it is hampered by inadequate intellectual abilities and limitations from authority figures in his life. This condition has caused the participant to be unable to fulfill his wishes, often eliciting anger and wanting to rebel. The participant, however, chooses to solve the problem by diverting to other things.

Distractions that are often used are crying and suicidal thoughts. These distractions illustrate that the participant's ego adequacy tends to be weak, with low problem-solving abilities and immature self-control. Apart from using distraction, the participant also suppresses his desire, causing intrapersonal conflicts to occur frequently within himself. Indirectly, this condition shows that the participant has quite a strong superego related to his life norms. He prefers to suppress his will and obey an authority figure.

The participant has memorable experiences from the past to the presentrelated to their behavior that has harmedothers. At this time, there is a strong feeling of fear, insecurity, and guilt. In the participant's environment, he is an individual with high solidarity. The participant also has a high need for nurturance, so he does not hesitate to sacrifice himself to protect his group or those closest to him. When faced with a situation that threatens himself and those closest to him, the participant often shows aggression by making physical contact. Moreover, the participant also feels that he is being ignored by the people he loves.

Participant 2 (SR) 
Based on the Thematic Apperception Test (TAT) results, it can be concluded that the participant tries to achieve his needs. However, when these needs are not met, they would feel sad. The participant feels that his mother has a good role in providing assistance and support when facing problems. The participant has a need to establish close relationships with the opposite sex, gain attention and warm treatment, and support to make the participant more productive.

The participant has a pretty good ability to empathize or understand others' feelings and problems. The participant has a need to establish friendships and provide entertainment for his friends. The participant also has a need to have fun with friends by violating discipline and moral rules even though the participant knows that this causes him to get into trouble. The participant also has a need to vent his disappointment by aggression against himself and others. Self-indulged aggression takes the form of dangerous behavior. In addition, there is a need to take revenge for the unpleasant treatment of others.

The participant has a need to escape from responsibility and seek freedom from stressful situations. However, he also has fear and anxiety about the threat of punishment for his actions. When in trouble, the participant will only surrender to the situation. The participant believes that women are weak and helpless figures when they experience betrayal and receive unpleasant treatment from the opposite sex.

\section{Participant 3 (YD)}

Based on the Thematic Apperception Test (TAT) results, it can be concluded that the participant is cognitively able to tell stories coherently, logically, and realistically. However, the stories' ending is dominated by stories that end with the participant showing low problem-solving skills. The participant tends to make decisions when conditions are not right. The participant does not live in an environment that supports his passion, so that participant is not given the freedom to choose the goals he wants to achieve independently. As an implication, the participant experiences internal conflict. He will achieve everything he wants to achieve with high ego and be less concerned about others' feelings and conditions by showing opposing and lying behavior even though he has received punishment. The participant also still needs love, attention, and support from his parents because he feels neglected. 
In social settings, the participant is an individual who is easily influenced by the environment, even though the environment expects him to do asocial behavior. However, the participant experiences a feeling of regret after making a mistake. This has caused the participant to have the desire to get away from bad things. However, he feels inadequate to do so because of the weak ego defense. He chooses inappropriate problem-solving strategies by avoiding them. The participant has a high enough need to behave in aggression and desire revenge when he feels betrayed. This is because he is concerned about the pain or injury he will receive. On the other hand, the participant has a need to carry out learning activities and study to become a successful individual and get recognition from others. Regarding relationships with other people, the participantdesires to have a close relationship with the opposite sex because he wants to be noticed and get affection from his closest person.

Based on the TAT results analysis, researchers focused on the psychological needs of the participants, as shown in Table I below:

Table I

Psychological Needs Analysis

\begin{tabular}{|c|c|c|}
\hline No & 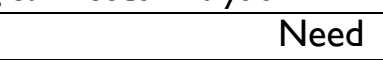 & Frequency \\
\hline I & Affiliation & 13 \\
\hline 2 & Succorance. & 13 \\
\hline 3 & Autonomy & 13 \\
\hline 4 & Aggression & 10 \\
\hline 5 & Achievement & 10 \\
\hline 6 & Sex & 9 \\
\hline 7 & Nurturance & 8 \\
\hline 8 & Understanding & 7 \\
\hline 9 & Avoidance & 6 \\
\hline 10 & Parental support & 5 \\
\hline II & Abasement & 5 \\
\hline 12 & Resistance & 4 \\
\hline 13 & Independence & 4 \\
\hline 14 & Passivity & 3 \\
\hline 15 & Counteraction & 3 \\
\hline 16 & Dominance & 2 \\
\hline 17 & Playmirth & 2 \\
\hline 18 & Recognition & 2 \\
\hline 19 & Fearful & 1 \\
\hline 20 & Acquisition & I \\
\hline
\end{tabular}


Based on the presentation of table I, it can be concluded that there were five needs (psychological needs) that have the highest frequency of appearing in all three participants, namely: (a) Affiliation, which is the need for warmth and support from others who direct the behavior to establish close relationships with other people, to be accepted, and liked; (b) Succorance, namely seeking help or sympathy, asking for help i.e., depending on others for encouragement, protection, and maintenance. Enjoying sympathy, food, or gifts from others. Feeling lonely when alone, longing when separated from someone, helpless in the face of a crisis. Escape to alcohol or drugs; (c) Autonomy, namely to free from or avoid an environment that restricts or forces, (d) Aggression, which consists of emotional verbal, physical social, physical asocial, and destructive; (e) Achievement, namely doing something important with energy and persistence, striving hard to carry out something valuable, and ambition that is embodied in the form of action.

The following are the psychological dynamics of the participants:

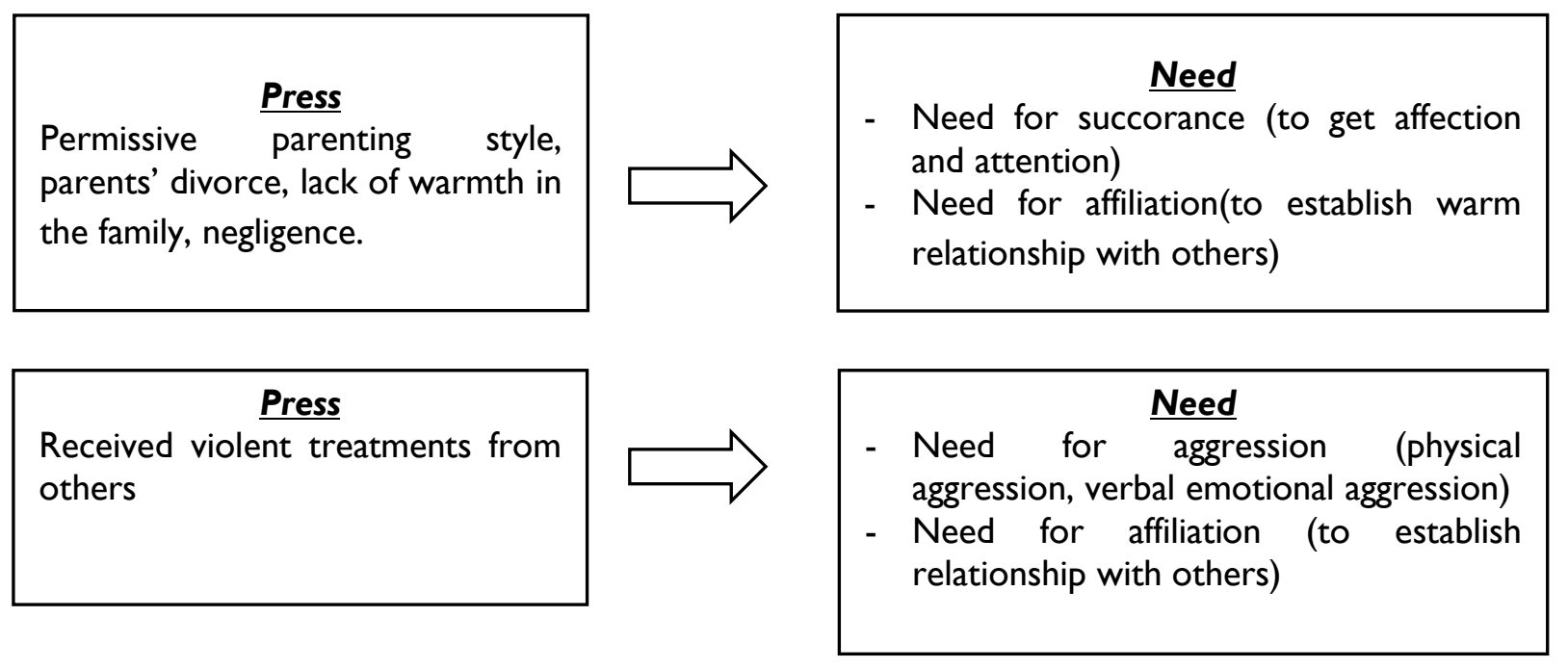

Figure I. Psychological dynamics of participant I (AA)

Based on Figure I, it can be explained that participant I (AA) has a high psychological need for love and attention from others (succorance) and has a high need to be able to establish warm relationships with friends and the opposite sex (affiliation). This is due to the presence of press from outside the participant, namely himself who gets permissive, and rather neglectful care from 
parents, so he does not get warmth and tends to be ignored in the family. These needs are also further strengthened by the condition of the divorcing parents. On the other hand, the participant also has a high psychological need for physical, verbal, and emotional aggressiveness. This is because he feels resentment for the displeasing treatment of others in the form of physical violence, such as being hit. In realizing their aggression needs, the participant also needs help from other figures so that there is also a need for affiliation.
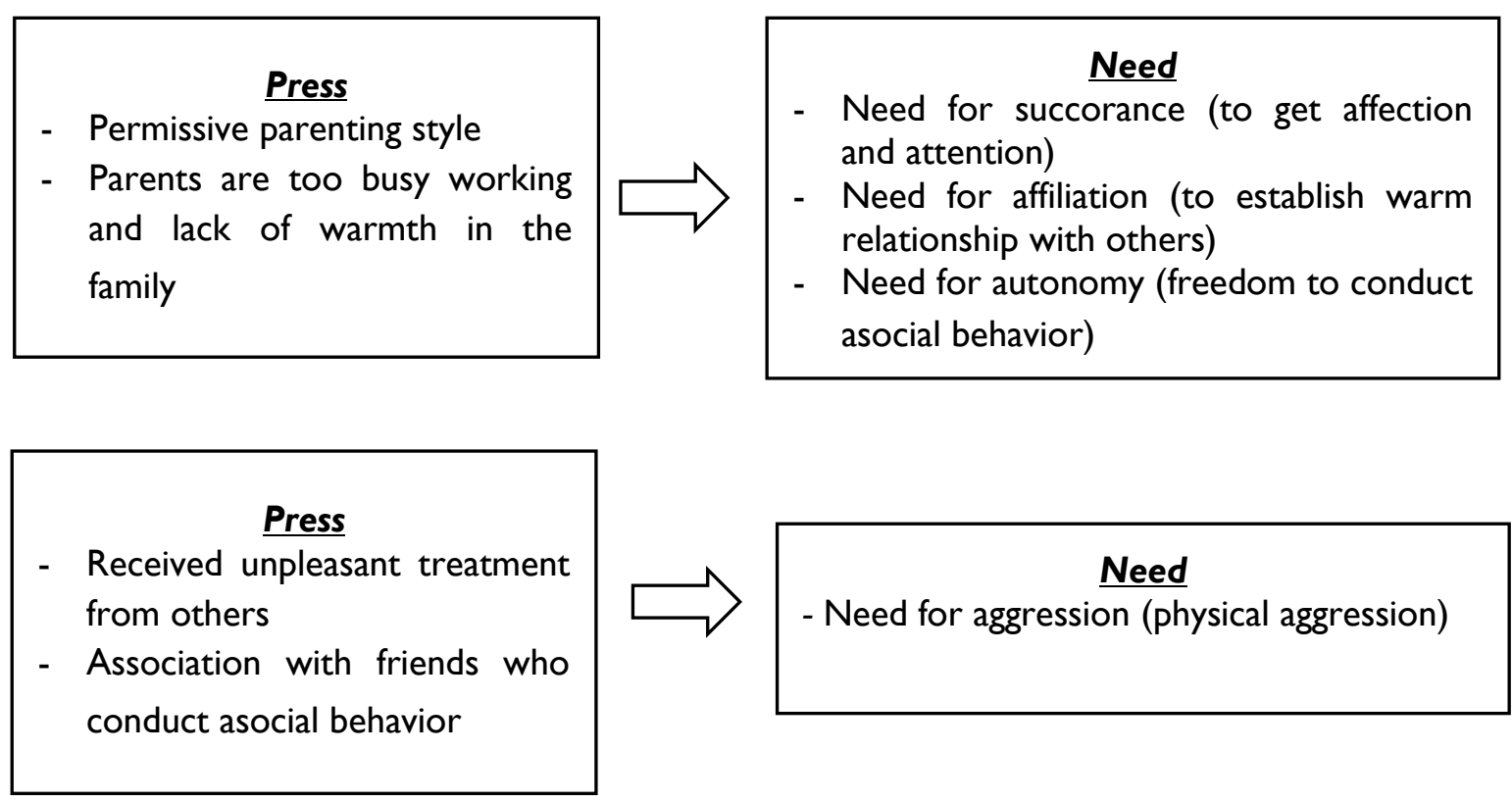

Figure II. Psychological dynamics of participant 2 (SR)

Based on figure II, it can be explained that participant 2 (SR) has a high psychological need for affection and attention from others (succorance) and has a high need to be able to establish warm relationships with other people such as friends and the opposite sex (affiliation). This is due to the press from outside of the participant, such as the permissive parenting style. The participant's parents are also busy working, so they do not receive warmth and tend to be neglected in the family. The press also makes the participant feel lonely and depressed. He needs freedom (autonomy) to be released from the pressure he is experiencing. In this case, the need for autonomy in the participant is in the form of asocial behavior. In addition, the participant also has a high psychological need for physical aggression. This is because he has feelings of resentment for the 
displeasing treatment of others to him and follows the association of peers who often commit aggressive acts in order to get social recognition.

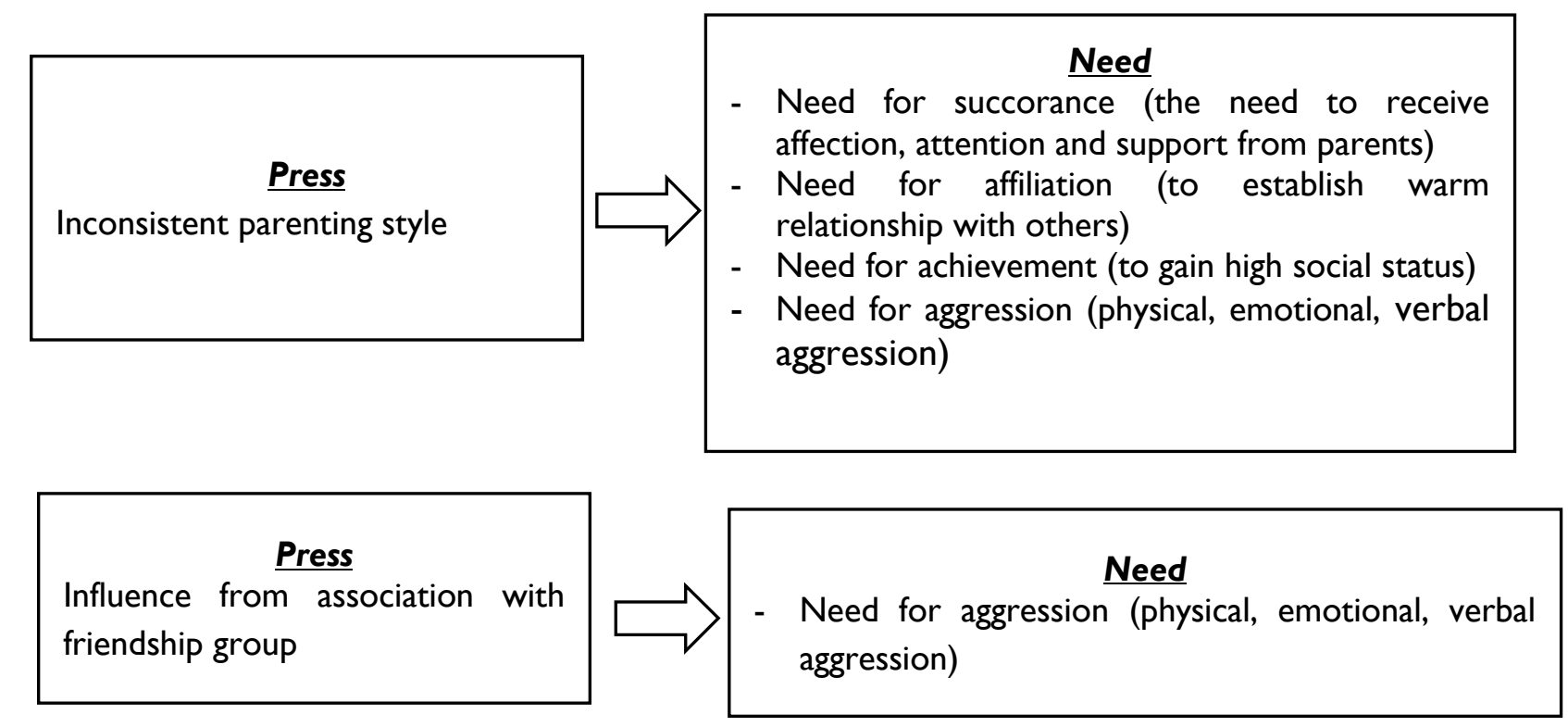

Figure III. Psychological dynamics of participant 3 (YD)

Figure III shows that participant 3 (DY) has a high psychological need for love and attention from others and parental support (succorance). In addition, he also has a high need to establish warm relationships with other people, such as friends and members of the opposite sex (affiliation). This is due to the press from outside of the participant, such as inconsistent parenting style. In this case, the mother tends to be dominant. She often commits acts of verbal violence to the participant. In contrast, the father tends to be permissive by rarely interacting with the participant and permits his behavior. Although the mother is dominant, the mother also rarely supervises the participant and tends to be liberating. This makes the participant receive less warm and positive affection from the family. Also, the participantneeds high achievement, especially in terms of social status. This is because he wants to be recognized by his family and environment. 
On the other hand, the participant also has a high psychological need to conduct aggressive behavior. This is due to the influence of his friends, who often act aggressively. With this, the participant becomes recognized by the environment. However, need for aggression also arises towards people who make participant feels hurt. The participant's need for aggression may also be compensation for feelings of helplessness over the treatment of mothers who often use verbal violence against him.

Based on the psychological dynamics that have been described in each participant, it can be concluded that the emergence of the dominant five needs (need for affiliation, succorance, autonomy, aggression, and achievement) was due to the press. The press experienced by the three participants tended to be under the same theme, related to the parenting style, which tended to be permissive and inconsistent and the social influence from the surrounding environment.

\section{Discussion}

Cognitive abilities and personality influence adult human behavior. According to psychoanalysis, humans are moved by impulsive unconscious impulses, which are then transformed into behavior. These impulses come from the id, ego, and superego, which complement the personality structure.

Based on the TAT results, the tendencies of the needs could be seen. The highest needs of klitih perpetrators were the need for affiliation, succorance, and autonomy, followed by the need for achievement and the need for aggression.

Based on the explanation above, it was shown that the klitih perpetrators' behavior was indeed based on the need for warmth and support from others, which directed the behavior to establish intimate relationships with others, be accepted, and liked. As stated by one of the participants below:

"So, I have several communities, miss. Yes, from the alumni association, school alumni are like an alliance, and there is also a community of football supporters, and party activists are also there hehehe so everyone, when there is an event, can come (interview with participant $A A$ ). 
This finding was in line with Sarasakti's (2013) research which showed that young gang members have high prosocial behavior to have a good relationship with their community. The existence of a gang was seen as a way for someone to fulfill the need for affiliation, dominant in klitih perpetrators. Klitih perpetrators did not act themselves, but the community/gang's existence triggered them. Klitih perpetrators need other people who accept and like them, which were found in the gangs they joined. However, the existence of the gang requires someone to perform klitih as a form of solidarity. McDonald \& Wood's (2018) research results confirmed a link between group reactions and feelings of acceptance or rejection with conformity behavior in adolescents. Aggressors tended to show expected behavior so that their existence was accepted and acknowledged. This finding also strengthened the results of previous research conducted by Fuadi et al. (2019), which explained that conformity was a determinant factor for klitih.

In this case, klitih perpetrators also have a high need for help or sympathy from others, including encouragement, protection, and maintenance. Klitih perpetrators feel lonely when they are alone. Hence, they feel more comfortable hanging out with people who understand them. Because of their dependence on other people, they tend to quickly run away to alcohol or drugs when they have problems. This is as conveyed by the participant below:

"the wife is really happy as his husband can go home." (TAT for participant SR)

Besides the need for help and sympathy, klith perpetrators also showed a high need for autonomy. They needed freedom. Breaking free or avoiding a restrictive or coercive environment was often manifested in the behavior of doing something without parents' approval or permission, as seen in one of the participant's TAT story:

"This boy is skipping school by going to the forest. They got drunk."

(TAT for participant SR)

This need for freedom is experienced starting in adolescence, where adolescents spend more time outside the home. This situation continues into adulthood. 
The next highest needs were need for aggression and need for achievement. In this case, the need for aggression included emotional aggression, physical aggression, social aggression, and destructive needs such as destroying and attacking others. Aggression is a characteristic of klitih perpetrators. When they are carrying out their actions, the perpetrator intentionally attacks the victim physically. This need for aggression belongs to all humans. However, the high need for aggression makes the id more dominant without any control from the superego, making the klitih perpetrator fulfill his needs through the victim. This study's results were also in line with Fuadi et al. (2019), which stated that one of the factors that influence klitih behavior was the character of individuals who cannot hold their emotions and tend always to want to vent negative emotions.

According to socio-cognitive theory, aggressive behavior shows a lack of ability to interpret situations (such as being easily offended and challenged when friends look at them), lack of knowledge to achieve goals correctly, and inability to evaluate responses appropriately. By showing aggressive behavior, the actors felt that they have succeeded in obtaining their rights and what they want only by doing so or losing the opportunity (Anantasari, 2006). Research by James \& LeBerton (2010) explained that aggressive behavior could be caused by the illusion of rational analysis in selfdefense mechanisms. The illusion of analysis was then used as a rationalization when doing actions that harm others.

This was in line with the participant's statement below,

"Usually when I gather, it's really crowded, but if not, there are 6-7 motorbikes, sometimes I feel disappointed because on the road we don't meet enemies, It is intentional that I want to look for enemies on the road hehehe, but there was a time when I was not able to find enemies, I threw stones to old men playing chess by the side of the road" (interview with participant $A A$ )

A few of the participants' stories showed need for aggression, one of which was shown below, 
"A child psychopath lives with his grandparents, since childhood his parents have left the child behind. He vented his feelings by being a psychopath and he likes it when someone was in pain and he also likes to see blood." (TAT for participant YD)

The need for achievement in klitih perpetrators was also quite high. Klitih perpetrators discussed what was important to them with energy and persistence. They tried hard to do something that they consider valuable. This ambition was manifested in the form of hurting others because of their high need to be considered brave by peer groups in their communities. As the participant said,

"in the sense of relief, maybe after he expresses his thoughts and feelings, he feels happy, relieved, because he can pour them into a song." (TAT for participant AA)

Other needs that also emerged in the TAT were need for sex, nurturance, understanding, harm avoidance, parental support, resistance, abasement, independence, counteraction, passivity, play mirth, recognition, fearful, and social acquisition.

The results showed that it was not only the need for aggression that served as the background of road violence (klitih) in Yogyakarta, but there were several other needs that also deserves attention. The actual needs of klitih perpetrators could also be channeled through other activities, so there was a need for alternative positive activities that could fulfill these five main needs for adolescents in order to prevent them from being involved in klitih behavior in schools, families, communities, and government.

\section{Conclusion}

Based on the interview analysis results and TAT, it appeared that there were five dominant psychological needs that klitih perpetrators have. The need for warmth and support (need for affiliation), the need to seek help or sympathy (need for succorance), the need for freedom (need for autonomy) seemed to emerge stronger. They were caused by the pressure from permissive family conditions and lack of warmth so that participants spent more time outside their homes. The need for violence (need for aggression) and the need for recognition (need for achievement) 
appeared to arise due to demands from the social environment, which influenced participants to perform klitih.

\section{References}

Aiken, L., \& Groth-Marnat, G. (2009). Pengetesan dan pemeriksaan psikologi. Jakarta: Penerbit Indeks.

Alwisol. (2007). Psikologi kepribadian. Malang: UMM Press.

Anantasari. (2006). Menyikapi perilaku agresif anak. Yogyakarta: Kanisius

Anastasi, A., \& Urbina, S. (2007). Tes psikologi (Edisi 7). Jakarta: Penerbit Indeks.

Andrianto \& Alimron. (2018). Faktor-faktor penyebab kenakalan remaja di Lebak Mulyo Kecamatan Kemuning Kota Palembang. Jurnal PAI Raden Fatah, I (I), 82-I04.

American Heritage Dictionary. (2010). Violence. http://ahdictionary.com/. 17 April 2019.

Bellak, L., \& Abrams, D. (1997). The TAT, The CAT, The SAT in Clinical Use. $6^{\text {th }}$ ed. Boston: Allyn \& Bacon.

Bushman, B. J., Newman, K., Calvert, S. L., Downey, G., Johns, M. D., Gottfredson, M., ...Johns, D. W. W., (2016). Youth violence: What we know and what we need to know. American Psychological Association, 7I(I), 17-39. http://dx.doi.org//0.1037/a00396.

Casmini \& Supardi. (2020). Family Resilience: Preventive solution of Javanese youth klithih behavior. The Qualitative Report, 25(4), 947-96I.

Fatimah, S., \& Umuri, M. T. (20I4). Faktor-faktor penyebab kenakalan remaja di desa Kemadang Kecamatan Tanjungsari Kabupaten Gunungkidul. Jurnal Citizenship, 4(I), 87-95.

Febriani, A. (2018). Klithih: Faktor resiko dan developmental pathway pelakunya. Humanitas, I5(2), 145-159.

Fuadi, A., Muti'ah, T., \& Hartosujono. (2019). Faktor-faktor determinasi perilaku klitih. Jurnal Spirits: Khasanah Psikologi Nusantara, 9(2), 88-98.

Gungea, M., Jaunky, V.S., \& Ramesh, V. (2017). Personality traits and juvenile deliquency. International Journal of Conception on Management and Social Sciences, 5(I), 2357-2787. 
Hall, C. S., \& Lindzey, G. (1993). Teori-teori holistik (Organismik - fenomenologis). Editor A. Supratiknya. Yogyakarta: Penerbit Kanisius.

James, L. R., \& LeBreton, J. M. (2010). Assessing aggression using conditional reasoning. Current Directions in Psychological Science, 19(I), 30-35.

Macdonald, C. T., \& Wood, J. K. (2018). The moderating effect of need for affiliation on conformity in response to group reactions. New Zealand Journal of Psychology (Online), 47(3), 28-37.

Moffitt, T. E., Caspi, A., Dickson, N., Silva, P. A., \& Stanton, W. (1996). Childhood-onset versus adolescent-onset antisocial conduct in males: Natural history from age 3 to 18. Development and Psychopathology. 8, 399-424. CrossRefGoogle Scholar.

Kennedy, T. D., Burnett, K. F., \& Edmonds, W. A. (20I I). Intellectual, behavioral, and personality of violent versus non-violent juvenile offenders. Aggressive Behavior, 37(4), 315-325.

Kipping, R. R., Campbell, R. M., MacArthur, G. J., Gunnell, D. J., \& Hickman, M. (2012). Multiple risk behaviour in adolescence. Journal of Public Health, 34(suppl I), il-i2. http://doi.org/I0.I093/.

Moranita, M., \& Huda, MJN. (2019). The dynamics of adolescent self-concept in lembaga pembinaan khusus anak Wonosari Yogyakarta. Jurnal Psikologi Integratif, 7(2). I04-I 2 I.

Oktaviani, D., \& Lukmawati. (2018). Keharmonisan keluarga dan kenakalan remaja pada siswa kelas 9 MTS negeri 2 Palembang. Jurnal Psikologi Islami, 4(I), 52-60.

Ozdemir, A., Utkualp, N., \& Pallos, A. (2016). Physical and psychosocial effects of the changes in adolescence period. International Journal of Caring Sciences, 9(2)7I 7-723.

Prabowo, A. (2016). Kesejahteraan psikologis remaja di sekolah. Jurnal Ilmiah Psikologi Terapan.4 (2), 246-260.

Reber, A., \& Reber, E. (2010). Kamus psikologi. Yogyakarta: Pustaka Pelajar.

Sarasakti, FMA. (20I3). Hubungan antara konformitas dan perilaku prososial pada remaja anggota geng di SMA Yogyakarta. Skripsi. Universitas Sanata Dharma Yogyakarta.

Sarwono, B. (2107). Mengendalikan kegaduhan sosial klitih dengan ketahanan keluarga. Prosiding Seminar dan Lokakarya Nasional Revitalisasi Laboratorium dan dan Jurnal Ilmiah dalam Implementasi Kurikulum Bimbingan dan Konseling berbasis KKNI. Malang.

Stahlberg, O., Anckarsater, H., \& Nilsson, T. (20I0). Mental health problems in youth committed to juvenile institutions: Prevalence and treatment needs. European Child \& Adolescent Psychiatry, 19(12), 893-903.

Sugiharto, K. (2017). Ada kelompok eksternal yang menghasut pelajar. Majalah Pranala. Hal 3 I. 
Sumara, D., Humaedi, S., \& Santoso, M. B. (2017). Kenakalan Remaja Dan Penanganannya. Jurnal Penelitian \& PPM, 4 (2), 129-389.

Suyanto, B. (2010). Masalah Sosial Anak. Jakarta: Kencana.

Syafi'l, M. (20I7). Yogyakarta darurat klitih. Yogyakarta: PUSHAM UII.

Tribun. (20I8). http://jogja.tribunnews.com/2018/I2/27/selama-20/8-I3-kasus-klitih-terjadi-diyogyakarta-dua-korban-meninggal-dunia.

Yusri, F. \& Jasmienti. (2017). Pengaruh pemenuhan kebutuhan remaja terhadap perilaku agresif siswa di PKBM Kasih Bundo Kota Bukittinggi. Journal of Islamic \& Social Studies. 3, (I), 95- 06.

WHO. (2019). Youth Violance. https://www.who.int/ akses 28 januari 2019.

Winarno, E. (2020). Klithih: Manifestasi penyimpangan agresivitas remaja. Media Informasi Penelitian Kesejahteraan Sosial, 44(I), 21-38. 